\title{
PEMETAAN ZONA EKOLOGIS DAN IDENTIFIKASI GEOMORFOLOGI LANSKAP GEO-AREA CILETUH DI KABUPATEN SUKABUMI
}

Mapping Of Ecological Zones And Identification Of Geomorphology Of Ciletuh Geo-Area Landscape In Sukabumi District

\section{Aisyah Sabilla Putri Hardini \\ Mahasiswa Sekolah Pascasarjana IPB, \\ Program Studi Arsitektur Lanskap \\ Email aisyahsabilla20@gmail.com}

\section{Afra DN Makalew}

Staf Pengajar Departemen Arsitektur Lanskap, Fakultas Pertanian IPB

\section{Aris Munandar}

Pengajar Departemen Arsitektur Lanskap, Fakultas Pertanian IPB

\begin{abstract}
Ciletuh-Palabuhanratu Geopark was officially approved by UNESCO on April 17, 2018 in Paris, France as part of the Global Geopark Network. The Ciletuh geo-area is an area with old fossils formed from the removal of stones in the subduction zone (estimated), estimated to be more than 50 million years old. On the other hand, the uniqueness and beauty of the natural resources possessed by the Ciletuh Geo-area can have a negative impact on oneself. This study discusses how to overcome ecological problems and talk about geomorphology as a way to overcome future problems. The results of the analysis showed that sensitivity to natural disasters was moderate (52.54\%) and land cover was $87.16 \%$ as fostered space so that it entered into the category of moderate ecological zone (72.03\%). The results of receiving geomorphology showed that as much as $57.06 \%$ of the rivers flowing in the study area were not resistant to erosion.
\end{abstract}

Keywords: Geo-area Ciletuh, Geomorphology, Ecological Zone

\section{PENDAHULUAN}

Jawa barat memiliki salah satu wilayah dengan potensi yang menjanjikan bagi kemajuan pariwisata, yaitu Kabupaten Sukabumi yang terletak di bagian selatan. Geopark Ciletuh-Palabuhanratu secara resmi diakui oleh UNESCO pada tanggal 17 April 2018 di Paris, Perancis sebagai bagian dari Global Geopark Network (Agusta 2018). Sejalan dengan itu, pemerintah Provinsi Jawa Barat merencanakan Geopark Ciletuh menjadi daerah tujuan wisata mancanegara dan akan di dukung sarana-prasarana seperti pembangunan bandara untuk mempermudah akses (Lavinda 2017). Geopark merupakan suatu konsep manajemen pengembangan kawasan secara berkelanjutan yang mengintegrasikan tiga keragaman yaitu keragaman geologi (geodiversity), keragaman hayati (biodiversity) dan keragaman budaya (cultural diversity) yang bertujuan untuk pembangunan serta pengembangan ekonomi kerakyatan berbasis pada asas konservasi terhadap ketiga keragaman tersebut (Azman et al. 2010). Geopark Ciletuh memiliki luas sekitar 126.100 Ha dan terbagi menjadi tiga geo-area dengan tema yang berbeda yaitu Geo-area Ciletuh dengan tema Fosil Subduksi, Geo-area Simpenan dengan tema Plato Jampang dan Geo-area Cisolok dengan tema Pergeseran Jalur Magnatik. Geo-area Ciletuh merupakan wilayah dengan keunikan fosil batuan tua yang terbentuk dari pengangkatan batuan di zona subduksi (penujaman), diperkirakan umur batuanya lebih dari 50 juta tahun. Peristiwa seperti ini terjadi di Lempeng Samudera Hindia atau bagian selatan Pulau Jawa (Lubis et al. 2010).

Secara alamiah, Geo-area Ciletuh memiliki bebatuan berkarakter yang terbentuk dari dua penggalan kerak bumi, yaitu lempeng samudera dan lempeng benua. Disisi lain, keunikan dan keindahan sumber daya alam yang dimiliki Geo-area Ciletuh mendapatkan dampak negatif yaitu adanya crosser dengan sengaja melindas Batu Batik atau Batu Naga yang diperkirakan berumur 55 juta tahun sebagai area bermain (Alamsyah $\mathrm{S}$ dan Gandapurnama B. 2017). Timbulnya dampak negatif sebagai akibat dari pengembangan wisata merupakan salah satu dasar diperlukannya sebuah manajemen untuk menciptakan pengalaman rekreasi yang berkualitas (Aukerman et al 2011). Untuk menanggulagi permasalahan atau mengantisipasi dampak negatif di masa depan, harus mulai mengidentifikasi potensi dan kelemahan di kawasan ini. Salah satu cara yang bisa di tempuh adalah dengan melakukan pemetaan zona ekologis lanskap sesuai dengan arahan dari Kementrian Pertanian (1980) tentang kriteria dan tata cara penetapan hutan lindung dengan tujuan menjaga agar kawasan dengan nilai ekologis tinggi dapat berfungsi dengan sebaik-baiknya maka tidak boleh dilaksanakan kegiatan yang menganggu atau merusak fungsi tersebut.

Keistimewaan geologi dari Geo-area Ciletuh adalah adanya jenis batuan tertua di Pulau Jawa pada formasi Sekis Pasir Luhur yaitu batuan pra-Tersier yang terdiri dari batuan metamorf dengan jenis batuan yaitu sekis, amfibolit, filit, kwarsit, gabro yang berselingan dengan peridotit (Sukamto 1975). Dalam upaya perlindungan dan perencanaan tata ruang sebagai kawasan pariwisata di Geo-area Ciletuh, maka perlu diperhatikan aspek-aspek geomorfologi agar dapat ditentukan lahan yang sesuai untuk suatu keperluan serta menentukan sebuah pola tata ruang berdasarkan aspek gemorfologi (Mangunsukardjo 2002). Tujuan dari penelitian ini adalah untuk mengidentifikasi dan menganalisis zona ekologis kawasan berdasarkan kepekaan lanskap terhadap erosi dan kondisi tutupan lahan di sekitar kawasan penelitian serta 
mengidentifikasi aspek geomorfologi Geo-area Ciletuh sebagai upaya untuk mengatasi masalah dan mengantisipasi dampak negatif di masa depan.

\section{METODOLOGI}

\section{Lokasi dan Waktu Penelitian}

Penelitian dilakukan di Geo-area Ciletuh, Kabupaten Sukabumi, Jawa Barat. Geo-area Ciletuh meliputi tiga kecamatan yaitu Kecamatan Ciemas, Kecamatan Ciracap, dan Kecamatan Surade dengan luas sekitar $58.373 \mathrm{Ha}$ atau $583.73 \mathrm{Km}^{2}$ (Gambar 1). Penelitian ini dilakukan selama 4 (empat) bulan di lapang, mulai dari bulan Februari sampai dengan Mei 2018.

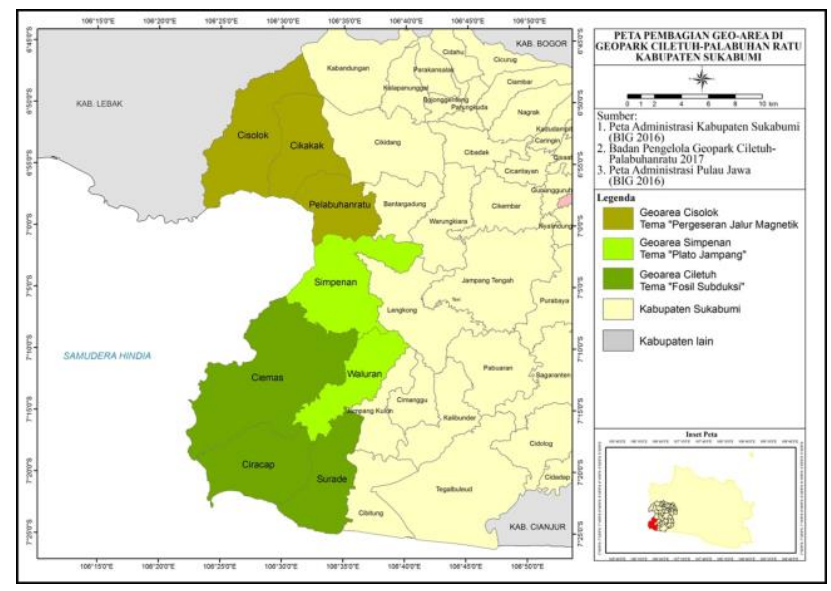

Gambar 1 Lokasi penelitian Geo-area Ciletuh di Kabupaten Sukabumi

\subsection{Alat dan Bahan}

Peralatan yang akan digunakan pada penelitian ini, meliputi kamera digital, seperangkat komputer, serta berbagai software seperti ArcMap 10.4, Erdas Imagine versi 9.1, Microsoft Word 2016, dan Microsoft Excel 2016. Bahan yang digunakan dalam penelitian ini adalah peta jenis tanah, data intensitas curah hujan tahun 2016, peta kemiringan lereng, peta pola aliran sungai, dan peta geologi.

\subsection{Metode Analisis Data}

Analisis zona ekologis lanskap menggunakan teknik overlay pada peta kepekaan lanskap dan peta penutupan lahan, sedangkan analisis geomorfologi merupakan sebuah pendekatan yang dilakukan untuk mengetahui bentuk lahan dan proses-proses yang mempengaruhi pembentukannya serta menyelidiki hubungan antara bentuk dan proses dalam tatanan keruangannya. Berikut adalah tahapan metode penelitian yang dilakukan.

\section{Pemetaan zona ekologis lanskap}

Analisis ini dilakukan pada dua parameter, yaitu kepekaan lanskap dan penutupan lahan dengan metode skoring dan pembobotan untuk menghasilkan zona ekologis kawasan. Penilaian kepekaan lanskap kawasan terhadap bencana alam dan kerusakan dilakukan pada tiga peubah yaitu kemiringan lereng, kepekaan tanah, dan intensitas curah hujan. Kriteria dan penilaian terhadap peubah kepekaan lanskap terdapat pada Tabel 1. Kemudian penilaian terhadap penutupan lahan dibagi kedalam tiga sub peubah yaitu ruang terbangun, ruang binaan dan ruang alami. Kriteria dan penilaian terhadap peubah penutupan lahan dapat dilihat pada Tabel 2. Perhitungan kepekaan lanskap kawasan dan penilaian penutupan lahan dilakukan dengan skoring pada setiap peubah yang ada kemudian dijumlahkan totalnya, dengan rumus:

\section{Keterangan:}

$$
\text { Skoring }=\sum B P
$$

$\mathrm{B}=$ Bobot $\quad \mathrm{P}=$ Nilai peubah

Selanjutnya setelah di skoring dan dilakukan pembobotan kemudian dikategorikan dalam kelas kepekaan, yaitu dengan perhitungan rumus :

Selang kelas kepekaan $=\frac{\sum \text { Skor maksimum }-\sum \text { Skor minimum }}{\sum \text { Peubah }}$ Hasil perhitungan menghasilkan tiga kategori untuk kelas kepekaan, yaitu kelas kepekaan rendah (45-104), sedang (105-164), dan tinggi (165-225). Arahan pengembangan dihitung dengan melakukan overlay hasil dari kelas kepekaan lanskap dengan penutupan lahan. Selanjutnya, zona ekologis kawasan dihasilkan dengan penjumlahan hasil skoring kepekaan lanskap dengan skoring penutupan lahan kemudian dibagi menjadi tiga kelas sehingga menghasilkan zona ekologis, yaitu zona ekologis rendah (65-138), zona ekologis sedang (138-211), dan zona ekologis tinggi (211-285). Analisis spasial dengan GIS dilakukan selanjutnya untuk menggambarkan setiap peubah yang dinilai dan diskoring sehingga dihasilkan petapeta tematik secara spasial yaitu peta kepekaan jenis tanah, peta intensitas curah hujan, peta kemiringan lereng, peta kepekaan lanskap, peta penutupan lahan, dan peta zona ekologis lanskap.

\section{Identifikasi dan deskripsi geomorfologi}

Identifikasi geomorfologi di Geo-area Ciletuh ditinjau dari aspek morfometri. Morfometri adalah aspekaspek kuantitatif dari suatu daerah seperti kemiringan lereng, bentuk lereng, ketinggian, kekasaran medan, bentuk lembah suatu sungai, tingkat pengikisan dan lainnya (Van Zuidam 1979) (Tabel 3). Dari perhitungan bentuk lahan secara kuantitatif tersebut, dapat dilihat juga bentuk lahan yang dihasilkan akibat adanya proses-proses geomorfik, data yang digunakan adalah kemiringan lereng. Selanjutnya, untuk mengidentifikasi jenis batuan dapat dilihat dari pola aliran sungai yang tersebar di Geo-area Ciletuh dan formasi geologi yang terbentuk melalui data sekunder. Pola aliran sungai akan saling bertemu dan 
membentuk suatu bentuk tertentu, hal tersebut dipengaruhi oleh faktor jenis batuan, topografi tanah, kekerasan batuan dan bentuk permukaan bumi (Van Zuidam 1985).

Tabel 1 Penilaian kepekaan lanskap Geo-area Ciletuh latosol merah kekuningan dan latosol coklat dengan presentase $27.48 \%$ atau seluas $160.42 \mathrm{~km}^{2}$ (Tabel 4).

Ciri dari jenis tanah laterik merah kekuningan adalah memiliki profil tanah yang dalam, mudah menyerap air dan memiliki bahan organik yang sedang dengan

\begin{tabular}{|c|c|c|c|c|c|}
\hline No & Peubah & Bobot & Sub peubah & Deskripsi & Nilai \\
\hline \multirow[t]{5}{*}{1} & Kemiringan & 20 & $0-8 \%$ & Datar & 1 \\
\hline & lereng & & $8-15 \%$ & Landai & 2 \\
\hline & & & $15-25 \%$ & Agak curam & 3 \\
\hline & & & $25-40 \%$ & Curam & 4 \\
\hline & & & $>40 \%$ & Sangat curam & 5 \\
\hline \multirow[t]{7}{*}{2} & Kepekaan & 15 & Aluvial, tanah glei planosol hidrowof kelabu, & Tidak peka & 1 \\
\hline & tanah & & laterit air tanah & & 2 \\
\hline & & & Latosol & Agak peka & 3 \\
\hline & & & Brown forest soil, non calcis brown, mediteran & Kurang peka & \\
\hline & & & Andosol, letrits, grumusol, podsol, padsolik & & 4 \\
\hline & & & Regosol, litosol, organozol, renzina & Peka & 5 \\
\hline & & & & Sangat peka & \\
\hline \multirow[t]{5}{*}{3} & Intensitas & 10 & $<13,6 \mathrm{~mm} /$ hari hujan & Sangat rendah & 1 \\
\hline & curah hujan & & $12,6-20,7 \mathrm{~mm} /$ hari hujan & Rendah & 2 \\
\hline & & & $20,7-27,7 \mathrm{~mm} /$ hari hujan & Sedang & 3 \\
\hline & & & $27,7-34,8 \mathrm{~mm} /$ hari hujan & Tinggi & 4 \\
\hline & & & $>34,8 \mathrm{~mm} /$ hari hujan & Sangat tinggi & 5 \\
\hline
\end{tabular}

Sumber: KEMENTAN (1980), Adriani (2016)

Tabel 2 Penilaian penutupan lahan di Geo-area Ciletuh

\begin{tabular}{llllll}
\hline No & Peubah & Bobot & Sub peubah & Deskripsi & Nilai \\
\hline $\mathbf{1}$ & Penutupan & 20 & Ruang & Permukiman, penginapan, dan lahan terbangun & 1 \\
& lahan & & terbangun & lainnya \\
& & Ruang binaan & Perkebunan, pertanian lahan kering, pertanian lahan & 2 \\
& & & kering bercampur semak, sawah, dan tanah terbuka \\
& & Ruang alami & Hutan lahan kering sekunder, hutan mangrove \\
& & & sekunder, hutan tanaman industri, tambak dan sungai & 3
\end{tabular}

Sumber: Hasil bimbingan (2017)

\section{HASIL DAN PEMBAHASAN}

\section{Pemetaan Zona Ekologis Lanskap}

Geo-area Ciletuh terdiri dari delapan klasifikasi kelompok jenis tanah yaitu aluvial coklat kelabu, aluvial hidromorf, kompleks laterik merah kekuningan dan podsolik, kompleks latosol coklat kemerahan dan litosol, kompleks latosol merah kekuningan dan latosol coklat, kompleks mediteran coklat kemerahan dan litosol, latosol coklat kekuningan dan regosol kelabu (Gambar 2). Hasil pengolahan data terhadap jenis tanah di Geo-area Ciletuh menunjukan bahwa yang mendominasi adalah jenis tanah kompleks laterik merah kekuningan dan podsolik dengan presentase nilai $46.44 \%$ atau seluas $271.08 \mathrm{~km}^{2}$ dan kompleks
$\mathrm{pH}$ netral hingga asam dan banyak mengandung zat besi dan alumunium sehingga baik digunakan sebagai pondasi bangunan. Tekstur tanah merah relatif padat dan kokoh untuk menopang bangunan diatasnya dan dapat digunakan untuk lahan perkebunan untuk jenis tanaman jagung, kelapa sawit, karet, cengkeh, kakao dan kopi. Jenis tanah aluvial coklat kelabu memiliki presentase paling kecil yaitu $0.88 \%$ atau seluas 5.12 $\mathrm{km}^{2}$. Jenis tanah ini banyak mengandung pasir dan liat, tidak banyak mengandung unsur-unsur zat hara dan memiliki kandungan bahan organik yang tinggi. Kandungan $\mathrm{pH}$ pada tanah ini tergolong rendah (5.3 5.8) dan kandungan alumunium terlarut sangat tinggi. Tingkat kepekaan jenis tanah terhadap erosi dikenal dengan istilah erodibilitas. Semakin peka jenis tanah, 
Tabel 3 Klasifikasi berdasarkan sudut lereng dan beda tinggi

\begin{tabular}{llll}
\hline No & Relief & $\begin{array}{l}\text { Kemiringan } \\
\text { lereng (\%) }\end{array}$ & Beda tinggi (m) \\
\hline $\mathbf{1}$ & Topografi datar atau hampir datar & $0-2$ & $<5$ \\
$\mathbf{2}$ & Bergelombang lemah - sedang/topografi landai & $3-7$ & $5-25$ \\
$\mathbf{3}$ & Bergelombang lemah - sedang/ topografi miring (lereng) & $8-13$ & $25-75$ \\
$\mathbf{4}$ & Bergelombang sedang - perbukitan/ topograi curam & $14-20$ & $50-200$ \\
$\mathbf{5}$ & Perbukitan - tersayat kuat/ topografi curam & $21-55$ & $200-500$ \\
$\mathbf{6}$ & Tersayat kuat - pegunungan / topografi sangat curam & $56-140$ & $500-1.000$ \\
$\mathbf{7}$ & Pegunungan / topografi hampir tegak & $>140$ & $>1.000$ \\
\hline
\end{tabular}

Sumber : Van Zuidam 1979

Tabel 4 Jenis tanah di Geo-area Ciletuh

\begin{tabular}{|c|c|c|c|}
\hline \multirow[t]{2}{*}{ No } & \multirow[t]{2}{*}{ Jenis tanah } & \multicolumn{2}{|l|}{ Luas } \\
\hline & & $\left(\mathrm{km}^{2}\right)$ & $(\%)$ \\
\hline 1 & Aluvial Coklat Kelabu & 5.12 & 0.88 \\
\hline 2 & Aluvial Hidromorf & 53.98 & 9.25 \\
\hline 3 & Kompleks Laterik Merah Kekuningan Dan Podsolik & 271.08 & 46.44 \\
\hline 4 & Kompleks Latosol Coklat Kemerahan dan Litosol & 25.39 & 4.35 \\
\hline 5 & Kompleks Latosol Merah Kekuningan dan Latosol Coklat & 160.42 & 27.48 \\
\hline 6 & Kompleks Mediteran Coklat Kemerahan dan Litosol & 53.99 & 9.25 \\
\hline 7 & Latosol Coklat Kekuningan & 5.49 & 0.94 \\
\hline 8 & Regosol Kelabu & 8.26 & 1.41 \\
\hline & Jumlah & 583.73 & 100.00 \\
\hline
\end{tabular}

Tabel 5 Kepekaan jenis tanah di Geo-area Ciletuh

\begin{tabular}{llll}
\hline $\mathbf{1}$ & Tidak peka & 59.10 & 10.12 \\
$\mathbf{2}$ & Agak peka & 191.31 & 32.77 \\
$\mathbf{3}$ & Kurang peka & 53.99 & 9.25 \\
$\mathbf{4}$ & Peka & 271.08 & 46.44 \\
$\mathbf{5}$ & Sangat peka & 8.26 & 1.41 \\
& Jumlah & 583.73 & 100.00 \\
\hline
\end{tabular}

maka semakin mudah tanah tersebut mengalami erosi. Erosi biasanya diakibatkan oleh kekuatan jatuhnya air hujan dan kekuatan aliran permukaan. Hasil analisis kepekaan jenis tanah di Geo-area Ciletuh terbagi menjadi lima kategori kepekaan tanah. Ketegori kepekaan tanah terluas yaitu peka dengan presentase $46.44 \%$ atau seluas $271.08 \mathrm{~km}^{2}$ dan kategori sangat peka adalah yang paling kecil yaitu $1.41 \%\left(8.26 \mathrm{~km}^{2}\right)$ (Tabel 5). Berdasarkan Rencana Tata Ruang Wilayah Kabupaten Sukabumi Tahun 2012 - 2032, pada daerah kepekaan jenis tanah peka dan sangat peka tidak boleh dilakukan pembangunan permanen maupun semi permanen kecuali untuk melindungi kawasan dan tidak boleh melakukan perubahan pada pengunaan lahannya. Ketentuan ini perlu dilaksanakan agar keberlanjutan kawasan Geo-area Ciletuh dapat terjaga dengan baik dan terhindar dari degradsi lanskap. Peta kepekaan jenis tanah menunjukan secara spasial bahwa sebagian besar kepekaan jenis tanah adalah peka, terutama pada bagian timur. Sedangkan agak peka sebagian besar di Kecamatan Ciemas dan beberapa bagian sangat peka di Kecamatan Ciemas dan Ciracap (Gambar 3).

Curah hujan di kawasan Geo-area Ciletuh berdasarkan pengamatan dari dua stasiun klimatologi di PT Goalpara (14.5 mm/hari) dan SMK Marangian (23.4 $\mathrm{mm} /$ hari) maka dikategorikan pada daerah yang memiliki intensitas curah hujan rendah dengan intensitasnya sebesar 13.6 - $20.7 \mathrm{~mm} /$ hari hujan sebanyak $100 \%$ atau seluas $587.73 \mathrm{~km}^{2}$. Tingkat intensitas curah hujan yang rendah di Geo-area Ciletuh membuat kawasan ini kemungkinan untuk terjadinya erosi lebih rendah. Namun berdasarkan hasil analisis kepekaan jenis tanah, luas area dengan kepekaan jenis tanah peka adalah yang tertinggi sehingga dapat terjadi erosi pada bulan-bulan tertentu 


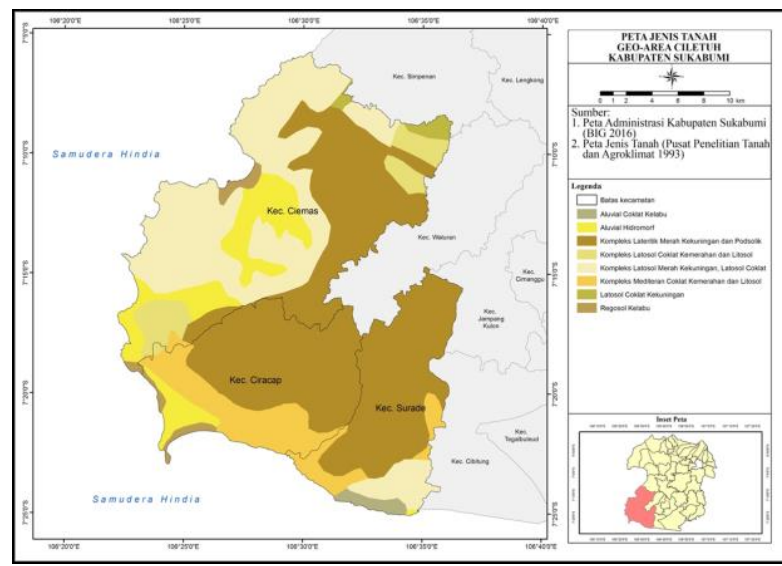

Gambar 2 Peta jenis tanah di Geo-area Ciletuh

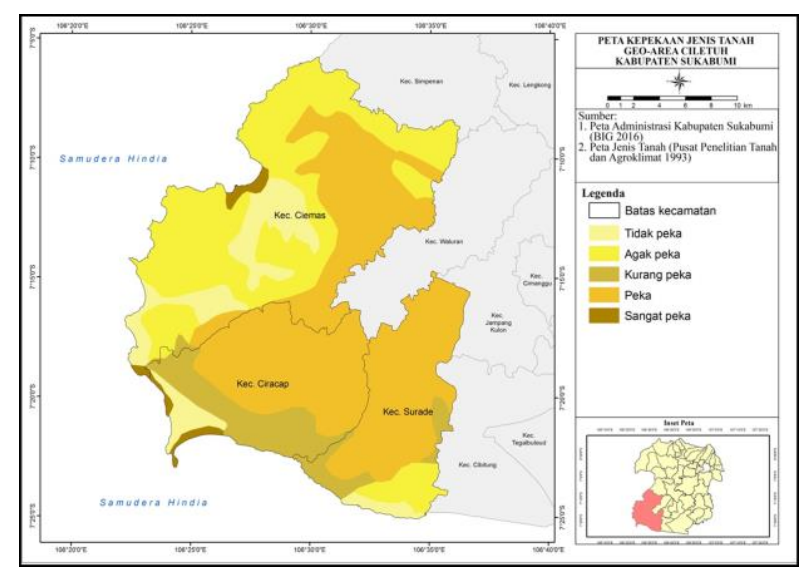

Gambar 3 Peta kepekaan jenis tanah di Geo-area Ciletuh

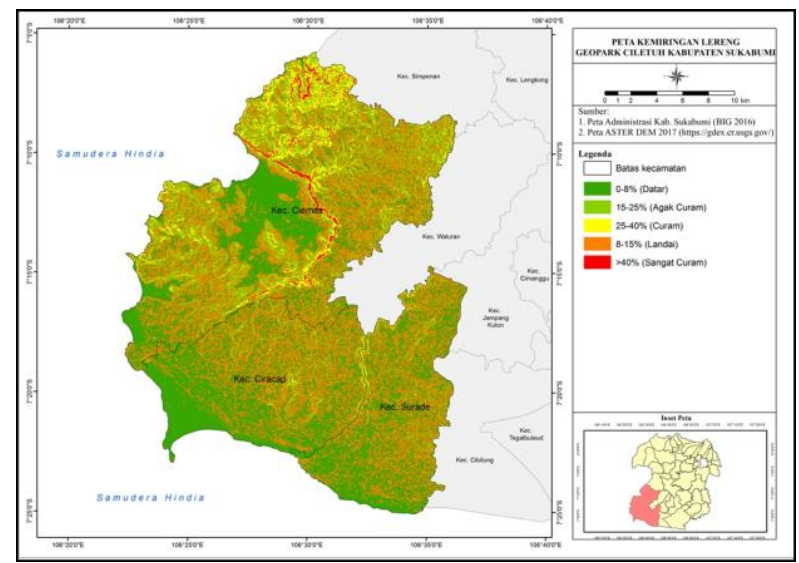

Gambar 4 Peta kemiringan lereng di Geo-area Ciletuh

yang memiliki intensitas curah hujan tinggi. Tingkat curah hujan yang rendah membuat kegiatan budidaya pertanian dapat berproduksi sangat baik karena tanaman tidak cepat busuk, bahkan terdapat sentra perkebunan Buah Naga. Terkait dengan aktivitas wisata maka jenis aktivitas luar ruangan menjadi sangat dominan, dikarenakan sebagian besar lokasi wisata di Geo-area Ciletuh adalah berbasis alam.

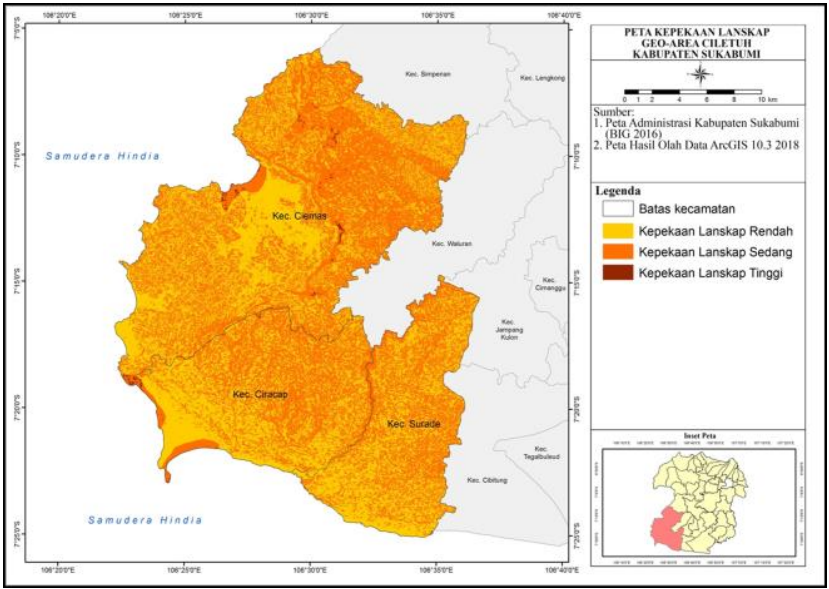

Gambar 5 Peta kepekaan lanskap di Geo-area Ciletuh

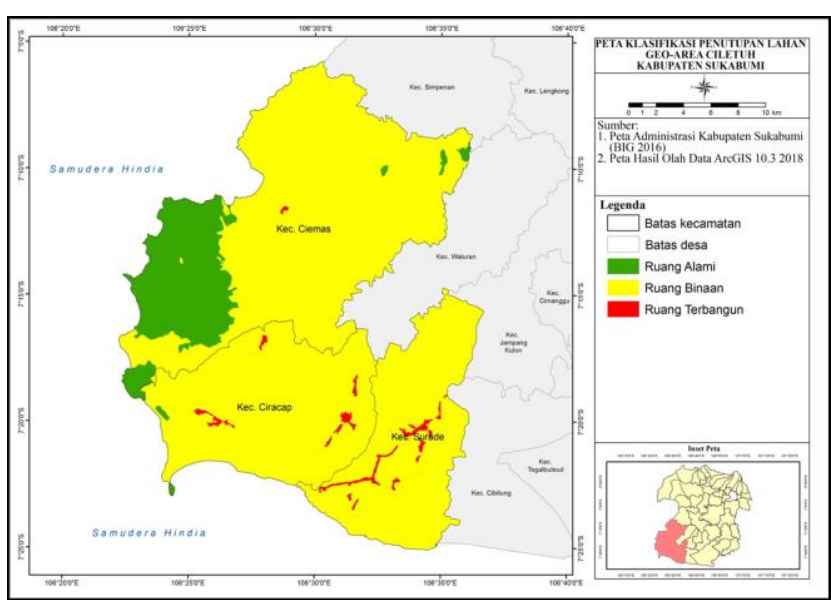

Gambar 6 Peta penutupan lahan di Geo-area Ciletuh

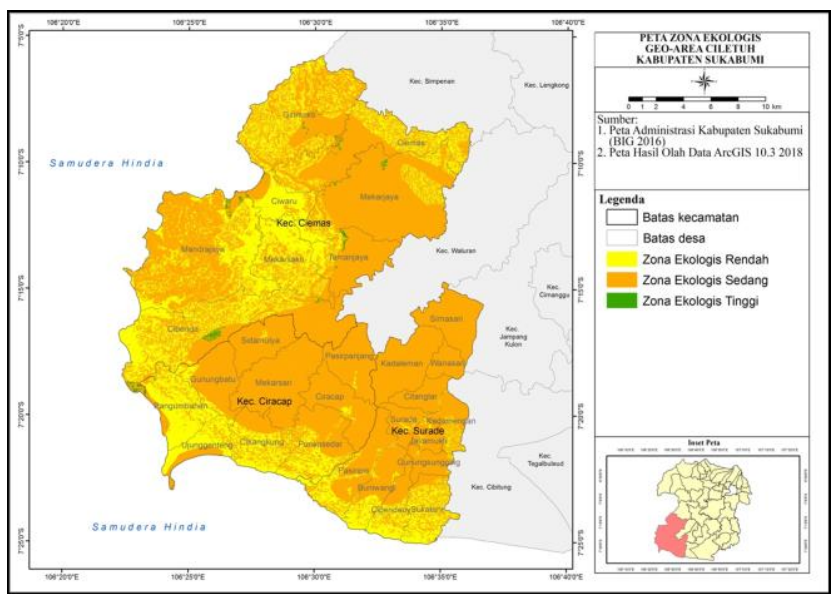

Gambar 7 Peta zona ekologis kawasan di Geo-area Ciletuh

Kemiringan lereng yang ada di Geo-area Ciletuh sangat beragam, terbagi menjadi lima kategori yaitu sangat curam, curam, agak curam, landai, dan datar. Dengan total presentase terbesar adalah kemiringan lereng datar yaitu $39.18 \%$ atau seluas $228.73 \mathrm{~km}^{2}$ dan 
kemiringan lereng landai yaitu $37.41 \%$ atau seluas $218.35 \mathrm{~km}^{2}$ (Tabel 6), kawasan ini didominasi dengan perbukitan sehingga kemiringan lerengnya adalah landai dan datar (Gambar 4).

Kepekaan lanskap diperoleh berdasarkan overlay dari tiga peta yaitu kepekaan jenis tanah, intensitas curah hujan, dan kemiringan lereng dengan hasil kategori kepekaan lanskap, yaitu kepekaan rendah, kepekaan sedang dan kepekaan tinggi (Gambar 5). Sebagai daerah tujuan wisata, kepekaan lanskap terhadap bencana alam atau kerusakan adalah hal yang utama untuk dikaji, karena menyangkut keselamatan dan keamanan wisatawan maupun masyarakat. Sehingga dalam perencanaan nantinya dijadikan bahan untuk mengantisipasi kerusakan di masa depan. Kelas kepekaan lanskap yang terbesar didominasi oleh kelas kepekaan lanskap sedang seluas $306.18 \mathrm{~km}^{2}$ atau $52.54 \%$, selanjutnya kepekaan lanskap rendah dengan luas wilayah $276.23 \mathrm{~km}^{2}$ atau $47.32 \%$, dan yang terakhir adalah kepekaan lanskap tinggi dengan luas wilayah $1.32 \mathrm{~km}^{2}$ atau $0.23 \%$ (Tabel 7).

Penutupan lahan di Geo-area Ciletuh ini dikategorikan menjadi tiga kelompok, yaitu ruang alami, ruang binaan, dan ruang terbangun. Hasil analisis penutupan lahan di Geo-area Ciletuh pada tahun 2017 menunjukan bahwa kawasan ini didominasi oleh ruang binaan sebesar $87.16 \%$ atau $508.80 \mathrm{~km}^{2}$ dikarenakan penggunaan lahan terbesar adalah pertanian lahan kering dan bercampur semak, selanjutnya ruang alami sebesar $11.78 \%$ atau 68.79 $\mathrm{km}^{2}$, dan hutan tanaman industri dan ruang terbangun sebesar $1.05 \%$ atau $6.14 \mathrm{~km}^{2}$ dengan penggunaan lahan permukiman (Tabel 8).Ruang alami terdiri dari hutan lahan kering sekunder, hutan mangrove sekunder dan hutan tanaman industri serta ruang terbuka biru berupa badan air, ruang ini memiliki nilai ekologis yang tinggi (Gambar 6). Pemetaan zona ekologis lanskap didapatkan dari overlay peta kepekaan lanskap dan penutupan lahan yang akan menghasilkan kondisi ekologis kawasan yang terbagi menjadi tiga yaitu zona ekologis tinggi, zona ekologis sedang, dan zona ekologis rendah. Berdasarkan hasil analisis didapatkan zona ekologis sedang adalah yang tertinggi yaitu sebesar $72.03 \%$ atau $420.48 \mathrm{~km}^{2}$ (Tabel 9 dan Gambar 7). Pemetaan zona ekologis kawasan di Geo-area Ciletuh dimaksudkan untuk dapat mengetahui area mana saja yang memiliki nilai ekologis tinggi, dimana tujuannya adalah untuk dilakukan perlindungan terhadap flora, fauna, dan juga secara fisik. Nilai ekologis yang tinggi menunjukan bahwa lanskap tersebut memiliki kepekaan yang tinggi dengan penutupan lahan yang masih alami. Sedangkan zona ekologis sedang memiliki kepekaan lanskap yang sedang pula dengan

Tabel 6 Kemiringan lereng di Geo-area Ciletuh

\begin{tabular}{llll}
\hline No & Kelerengan & $\begin{array}{l}\text { Luas } \\
\left(\mathrm{km}^{2}\right)\end{array}$ & $(\%)$ \\
\hline $\mathbf{1}$ & $0-8 \%$ (Datar) & 228.73 & 39.18 \\
$\mathbf{2}$ & $15-25 \%$ (Agak Curam) & 104.40 & 17.88 \\
$\mathbf{3}$ & $25-40 \%$ (Curam) & 26.32 & 4.51 \\
$\mathbf{4}$ & $8-15 \%$ (Landai) & 218.35 & 37.41 \\
$\mathbf{5}$ & $>40 \%$ (Sangat Curam) & 5.93 & 1.02 \\
& Jumlah & 583.73 & 100.00 \\
\hline
\end{tabular}

Tabel 7 Kepekaan lanskap di Geo-area Ciletuh

\begin{tabular}{llll}
\hline No & Kelas & $\begin{array}{l}\text { Luas } \\
\left(\mathrm{km}^{2}\right)\end{array}$ & $(\%)$ \\
\hline $\mathbf{1}$ & Kepekaan lanskap rendah & 276.23 & 47.32 \\
$\mathbf{2}$ & Kepekaan lanskap sedang & 306.18 & 52.45 \\
$\mathbf{3}$ & Kepekaan lanskap tinggi & 1.32 & 0.23 \\
& Jumlah & 583.73 & 100.00 \\
\hline
\end{tabular}

Tabel 8 Penutupan lahan di Geo-area Ciletuh

\begin{tabular}{llll}
\hline No & Kelas & $\begin{array}{l}\text { Luas } \\
\left(\mathrm{km}^{2}\right)\end{array}$ & $(\%)$ \\
\hline $\mathbf{1}$ & Ruang alami & 68.79 & 11.78 \\
$\mathbf{2}$ & Ruang binaan & 508.80 & 87.16 \\
$\mathbf{3}$ & Ruang terbangun & 6.14 & 1.05 \\
& Jumlah & 583.73 & 100.00 \\
\hline
\end{tabular}


Tabel 9 Zonasi ekologis kawasan di Geo-area Ciletuh

\begin{tabular}{llll}
\hline No & Kelas & $\begin{array}{l}\text { Luas } \\
\left(\mathrm{km}^{2}\right)\end{array}$ & $(\%)$ \\
\hline $\mathbf{1}$ & Zona ekologis tinggi & 161.34 & 27.64 \\
$\mathbf{2}$ & Zona ekologis sedang & 420.48 & 72.03 \\
$\mathbf{3}$ & Zona ekologis rendah & 1.92 & 0.33 \\
& Jumlah & 583.73 & 100.00 \\
\hline
\end{tabular}

Tabel 10 Jenis batuan di Geo-area Ciletuh

\begin{tabular}{|c|c|c|c|c|c|c|}
\hline No & $\begin{array}{l}\text { Kemiringan } \\
\text { lereng (\%) }\end{array}$ & $\begin{array}{l}\text { Beda } \\
\text { tinggi } \\
\text { (mdpl) }\end{array}$ & Relief & Satuan & $\begin{array}{l}\text { Luas } \\
\left(\mathbf{k m}^{2}\right) \quad(\%)\end{array}$ & \\
\hline 1 & $0-2 \%$ & $>5$ & Topografi dataran & Datar & 0.72 & 0.12 \\
\hline 2 & $3-7 \%$ & $5-25$ & $\begin{array}{l}\text { Topografi bergelombang } \\
\text { lemah }\end{array}$ & Landai & 100.85 & 17.28 \\
\hline 3 & $8-13 \%$ & $25-50$ & $\begin{array}{l}\text { Topografi bergelombang } \\
\text { lemah-kuat }\end{array}$ & Miring & 85.39 & 14.63 \\
\hline 4 & $21-55 \%$ & $50-200$ & $\begin{array}{l}\text { Topografi perbukitan- } \\
\text { tersayat kuat }\end{array}$ & Cukup curam & 216.47 & 37.08 \\
\hline 5 & $14-20 \%$ & $200-500$ & $\begin{array}{l}\text { Topografi bergelombang } \\
\text { lemah-perbukitan }\end{array}$ & Curam & 145.77 & 24.97 \\
\hline 6 & $56-140 \%$ & $500-1000$ & $\begin{array}{l}\text { Topografi perbukitan- } \\
\text { tersayat kuat }\end{array}$ & Sangat curam & 34.53 & 5.92 \\
\hline 7 & $>140 \%$ & $>1000$ & Topografi pegunungan & Hampir tegak & - & - \\
\hline & & & Jumlah & & 583.73 & 100 \\
\hline
\end{tabular}

penutupan lahan seperti pertanian, perkebunan, dan sawah. Meskipun merupakan ruang binaan, zona ini tetap harus dilakukan perlindungan dengan tidak membuat struktur bangunan diatasnya kecuali untuk kepentingan perlindungan. Zona ekologis rendah memiliki kepekaan lanskap yang rendah pula dengan penutupan lahannya permukiman, penginapan, dan ruang terbangun lainnya sehingga zona ini boleh membangun struktur untuk kepentingan pariwisata.

Perlindungan terhadap kawasan dengan nilai ekologis tinggi didukung oleh Peraturan Direktur Jenderal Konservasi Sumber Daya Alam dan Ekosistem Nomor P.11 / KSDAE / SET / KSA.0 / 9 / 2016 tentang penyusunan rancangan zona pengelolaan kawasan suaka alam dan kawasan pelestarian alam. Dalam peraturan ini dilakukan pendekatan ekologi lanskap yaitu dengan membagi kawasan konservasi ke dalam unit-unit satuan lanskap untuk memudahkan dalam pembagian blok pengelolaan. Lanskap Geo-area Ciletuh merupakan kawasan dengan keunikan, keragaman, dan keindahan dari sumber daya alam yang dimiliki, seperti fosil batuan tua, area perbukitan dan curug yang tersebar di banyak titik, maka pengelolaanya harus terselenggara dengan menjaga keseimbangan ekologi sebagai daerah hilir yang memililki fungsi ekologis tinggi. Selain itu, gagasan perlindungan pada zona ekologis tinggi ditetapkan dalam RTRW Kabupaten Sukabumi tahun 2012-2032 dalam kebijakan dan strategi penataan ruang, diantaranya adalah pengembangan wisata budaya, wisata alam, dan wisata buatan memanfaatkan potensi alam dan memperhatikan kelestarian lingkungan hidup dan budaya, menetapkan kawasan-kawasan di luar kawasan hutan yang mempunyai fungsi lindung menjadi kawasan lindung, dan membatasi pengembangan prasarana wilayah di sekitar kawasan lindung. Geo-area Ciletuh masuk kedalam zona ekologis sedang yaitu sebanyak $72.03 \%$ dari total kawasan atau seluas $420.48 \mathrm{~km}^{2}$. Pada zona ini harus dilakukan penataan atau pengelolaan yang berbasis pada kelestarian alam untuk mengantisipasi terjadinya bencana alam yang juga dapat terjadi karena adanya penyalahgunaan pemanfaatan lahan. Berdasarkan analisis kepekaan lanskap, menunjukan bahwa Geoarea Ciletuh merupakan area yang rawan terhadap bencana alam seperti erosi (tingkat kepekaan jenis 
Tabel 11 Jenis batuan di Geo-area Ciletuh

\begin{tabular}{|c|c|c|c|c|c|}
\hline No & Jenis batuan & Pola aliran & Formasi batuan & $\begin{array}{l}\text { Luas } \\
\left(\mathbf{k m}^{2}\right)\end{array}$ & $(\%)$ \\
\hline 1 & Batu breksi tufa & $\begin{array}{l}\text { Dendritik halus } \\
\text { (rapat) }\end{array}$ & Formasi Jampang & 216.49 & 37.09 \\
\hline 2 & $\begin{array}{l}\text { Batu pasir } \\
\text { kwarsa }\end{array}$ & $\begin{array}{l}\text { Dendritik halus } \\
\text { (rapat) }\end{array}$ & $\begin{array}{l}\text { Anggota Cikarang - } \\
\text { Formasi Cibodas }\end{array}$ & 80.54 & 13.08 \\
\hline 3 & $\begin{array}{l}\text { Batu pasir } \\
\text { gamping }\end{array}$ & $\begin{array}{l}\text { Dendritik halus } \\
\text { (rapat) }\end{array}$ & $\begin{array}{l}\text { bagian bawah Formasi } \\
\text { Bentang }\end{array}$ & 40.24 & 6.89 \\
\hline 4 & Batu pasir tufa & $\begin{array}{l}\text { Dendritik rapat } \\
\text { (renggang) }\end{array}$ & Formasi Jampang & 57.05 & 9.77 \\
\hline 5 & Batu pasir tufa & Trellis & $\begin{array}{l}\text { Anggota Ciseureuh - } \\
\text { Formasi Cibodas }\end{array}$ & 33.62 & 5.76 \\
\hline 6 & Batu lempung & Rektangular & Formasi Ciletuh & 132.04 & 22.62 \\
\hline 7 & $\begin{array}{l}\text { Batu endapan } \\
\text { aluvial pantai }\end{array}$ & Pararel & $\begin{array}{l}\text { Anggota Aluvial \& } \\
\text { Endapan Koastal }\end{array}$ & 23.76 & 4.07 \\
\hline
\end{tabular}

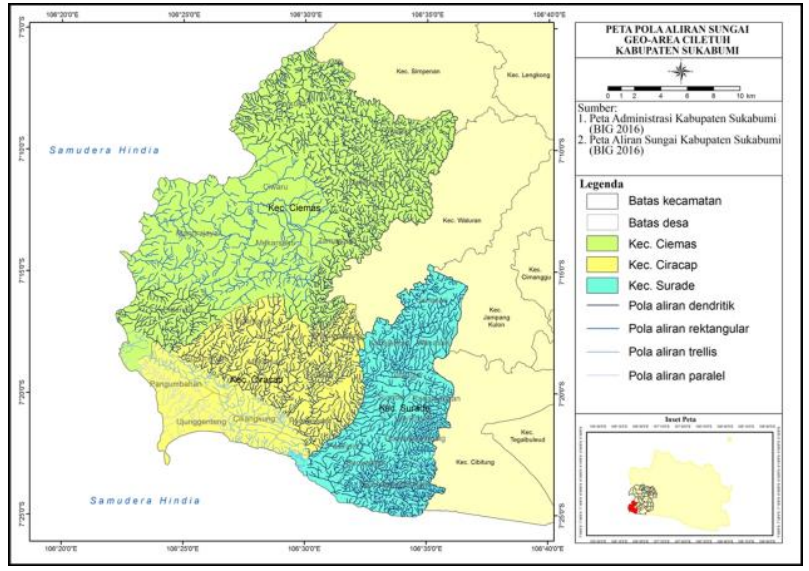

Gambar 9 Peta pola aliran sungai di Geo-area Ciletuh

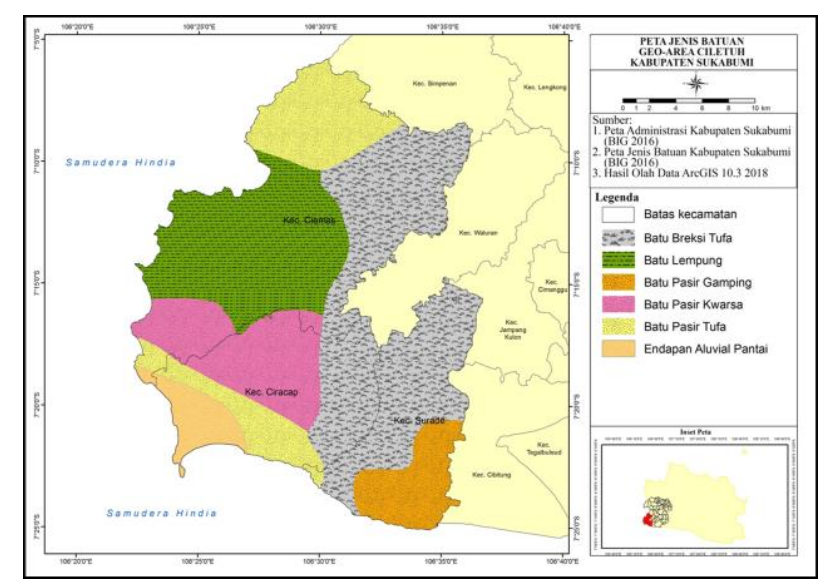

Gambar 10 Peta Jenis batuan Geo-area Ciletuh

tanah $46.44 \%$ ). Sehingga pada perencanaan lanskap akan dibuat konsep mitigasi bencana yang bertujuan untuk mengurangi dan mengantisipasi dampak buruk yang mungkin terjadi.

\section{Identifikasi dan Deskripsi Geomorfologi}

Geomorfologi Geo-area Ciletuh yang bervariasi dari mulai daratan hingga pinggir pantai dan di dominasi oleh relief bergelombang lemah sebesar $35.36 \%$ ini berpengaruh terhadap kemiringan lereng dan secara morfometri adalah cukup curam sebesar $37.08 \%$ (Tabel 10) . Kecamatan Ciemas (bagian utara) memiliki relief beragam, yaitu topografi bergelombang lemah hingga perbukitan bergelombang lemah (landai hingga curam) dengan dominasi curam. Sebagian besar penggunaan lahan di kawasan ini adalah pertanian lahan kering, hutan tanaman industri, dan pertanian lahan kering dengan semak. Kecamatan Ciracap (bagian tengah) memiliki relief yang sama dengan Kecamatan Ciemas namun didominasi relief cukup curam atau dengan topografi perbukitan tersayat kuat dan penggunaan lahan pada kecamatan ini didominasi oleh pertanian lahan kering. Sedangkan Kecamatan Surade (bagian selatan) memiliki relief landai hingga cukup curam dengan dominasi cukup curam dengan dominasi penggunaan lahan untuk pertanian lahan kering dan sawah (Gambar 8).

Berdasarkan pengelompokan dari pola aliran sungai yang tersebar di Geo-area Ciletuh, didapatkan empat pola yaitu dendritik, pararel, trellis dan rektangular (Gambar 9). Pola dendritik berbentuk seperti cabang pohon dan berada di daerah datar dengan struktur batuan homogen, pola pararel biasanya terbentuk oleh lereng yang curam/ terjal, pola trellis berada sejajar dengan induk sungainya dan berada dibawah patahan, dan pola rektangular adalah pola aliran yang dikendalikan oleh struktur geologi, seperti struktur kekar (rekahan) dan sesar (patahan). 
Pola aliran dendritik halus (rapat) terbentuk sebesar $37.09 \%$, jenis batuan yang terkandung disini kurang resisten terhadap erosi. Sedangkan pola aliran dendritik kasar (renggang) yang terbentuk sebesar 9.77\% mengandung jenis batuan yang resisten terhadap erosi. Resistensi batuan terhadap erosi ini akan sangat mempengaruhi proses pembentukan aluralur sungai, maka suatu sistem pengaliran sungai yang mengalir pada batuan yang tidak resisten akan membentuk pola jaringan sungai yang rapat (tekstur halus), sedangkan sebaliknya pada batuan yang resisten akan membentuk kasar (Noor 2014). Pola aliran rektangular terbentuk sebesar $22.62 \%$, biasanya terjadi pada struktur batuan beku yang resisten terhadap erosi. Selanjutnya dilakukan delineasi berdasarkan pola yang ada dan didapatkan tujuh jenis batuan utama di Geo-area Ciletuh, yaitu batu pasir tufa, batu breksi tufa, batu lempung, batu pasir kwarsa, batu endapan aluvial pantai, dan batu gamping (Gambar 10). Jenis batuan yang terkandung diketahui dari formasi yang terbentuk di area tersebut. Sebagian besar pola aliran yang terbentuk adalah dendritik kasar (rapat) dan terdiri dari batuan kasar seperti batu breksi tufa $(37.09 \%)$ dan batu pasir kwarsa (13.80\%) dengan struktur yang kuat (Tabel 11). Keduanya merupakan batuan sedimen dari gunung api. Batu pasir biasanya berwarna coklat dan putih dan batu breksi berwarna merah kecoklatan, keemasan dan coklat. Batu breksi tersusun atas batuan dengan fragmen menyudut (tajam), dapat dijumpai pada Komplek Batu Naga di Geo-area Ciletuh dan batu pasir merupakan batuan sedimen klastik yang dimana partikel penyusunnya kebanyakan berupa butiran pasir yang terbawa oleh pergerakan air, seperti ombak. Sedangkan batuan yang paling lunak berada di endapan Anggota Aluvial dan Endapan Koastal (4.07 $\%)$ atau daerah wisata Ujung Genteng, berdasarkan tempat pengendapannya termasuk ke endapan pantai/marine yang terjadi akibat proses pengendapannya di laut dengan kedalaman $<200$ meter diatas permukaan laut dan materi yang terbawa biasanya bertekstur kasar. Endapan ini terjadi dalam kondisi lepas - lepas sehingga belum terkonsolidasi dengan kompak atau belum menjadi batuan sedimen. Salah satu keunikan yang terdapat di Geo-area Ciletuh yaitu adanya Formasi Sekis Pasir Luhur dimana batuan yang tekandung didalamnya merupakan batuan metamorf dengan umur pra-tersier dan yang tertua di Pulau Jawa. Proses metamorfosisme tersebut terjadi di dalam bumi pada kedalaman $3 \mathrm{~km}-20 \mathrm{~km}$. Satuan ini terdiri atas sekis, amfibolit, filit, kwarsit, dan gabro yang berselingan dengan peridotit.

\section{SIMPULAN DAN SARAN}

Hasil dalam penelitian ini, Geo-area Ciletuh masuk kedalam kategori zona ekologis sedang dengan wilayah yang rawan/resisten terhadap erosi. Analisis kepekaan lanskap menunjukan hasil 52.45\% kepekaan lanskap adalah sedang yang terdiri dari kepekaan jenis tanah terhadap erosi sebesar 46,44\%, meskipun memiliki intensitas curah hujan rendah, potensi erosi akan muncul pada saat musim hujan tiba dan wilayah ini berada pada area perbukitan landai hingga curam. Selain itu, dari pola aliran sungai dan jenis batuan yang terbentuk di Geo-area Ciletuh menunjukan bahwa seluas $57.06 \%$ daerah tidak resisten terhadap erosi, karena terbentuk dari struktur batuan beku yaitu Breksi Tufa dan membentuk pola aliran sungai dendritik rapat. Berdasarkan hasil analisis yang sudah dilakukan, Geo-area Ciletuh berada pada zona rawan bencana terutama banjir dan tanah longsor yang disebabkan oleh erosi tanah. Sehingga perlu dilakukan analisis selanjutnya mengenai risiko bencana banjir dan tanah longsor serta perlu disusunnya perencanaan mitigasi bencana untuk mengantisipasi dan mengurangi dampak buruk yang akan terjadi.

\section{DAFTAR PUSTAKA}

[BPS] Biro Pusat Statistik Provinsi Daerah Istimewa Adriani, H. 2016. Perencanaan Lanskap Kawasan Wisata Berkelanjutan di Kecamatan Cisarua Kabupaten Bogor. [Tesis]. Bogor(ID): Institut Pertanian Bogor.

Alamsyah S., Gandapurnama B. 2017. Pesona Batu Jutaan Tahun di Ciletuh Geopark yang Dilindas Crosser. [Internet]. [diunduh 2017 Sept 14]. https://news.detik.com/berita-jawa-barat/d3580295/pesona-batu-jutaan-tahun-di-geoparkciletuh-yang-dilindas-crosser.

Aukerman, H. 2011. Water and Land Recreation Opportunity Spectrum (WALROS). Colorado: U.S. Department of the Interior Bureau of Reclamation.

Azman N., Sharina A., Ong PL, Salsela S., Ibrahim K. 2010. Public education in heritage conservation for geopark community. Procedia social and behavioral sciences. 7(c): $\quad 504-511$.

Dasiharjo, SU., Saputra IM. 2016. Pengembangan Geopark Ciletuh Berbasis Partisipasi Masyarakat Sebagai Kawasan Geowisata di Kabupaten Sukabumi. Jurnal Manajemen Resort dan Leisure, Vol. 13 No.1, 55-60.

[DIRJENKSDAE] Direktur Jenderal Konservasi Sumber Daya Alam dan Ekosistem. Peraturan Direktur Jenderal Konservasi Sumber Daya Alam dan Ekosistem Nomor P.11/KSDAE/SET/KSA.0/9/2016 tentang Petunjuk Teknis Rancangan Zona Pengelolaan atau Blok Pengelolaan Kawasan Suaka Alam dan Kawasan Pelestarian Alam.

[KEMENPAR] Kementrian Pertanian. 1980. Keputusan Menteri Pertanian Nomor 837/Kpts/Um/11/1980 Tanggal 24 Nopember 1980 tentang Kriteria dan Tata Cara Penetapan Hutan Lindung. 
doi : 10.29244/jli.2018.10.2.81-90

Lavinda. 2017. Menhub sebut tiga opsi lokasi bandara baru di Sukabumi. [Internet]. [diunduh 2017 Des 19].

https://www.cnnindonesia.com/ekonomi/201 71107204012-92-254192/menhub-sebut-tigaopsi-lokasi-bandara-baru-di-sukabumi.

Mangunsukardjo, K. 2002. Kajian Geomorfologi Untuk Perencanaan Penggunaan Lahan di Daerah Aliran Sungai Oyo, Gunungkidul, Daerah Istimewa Yogyakarta. Majalah Geografi Indonesia. Fakultas Geografi Universittas Gadjah Mada.

Noor, D., 2014. Pengantar Geologi. Yogyakarta: Deepublish

Sukamto, R. 1975. Geologi Lembar Jampang dan Balekambang Jawa. Pusat Penelitian dan Pengembangan Geologi Direktorat Pertambangan Umum Departemen Pertambangan dan Energi, Bandung, Indonesia.

[PP] Peraturan Pemerintah Republik Indonesia Nomor 26 Tahun 2008 tentang Rencana Tata Ruang Wilayah Nasional.

Zuidam, RAV. 1979. Guide to Morphology Areal Topographic Interpretation and Mapping. ITC Textbook of photo interpretation vol VII, International Institute for Aerial Survey and Earth Science, Netherlands, 230.

Zuidam, RAV. 1985. Aerial Photo-Interpretation Terrain Analysis and Geomorphology Mapping.

Smith Publisher The Hague, IT 
